\title{
Battery energy storage technologies overview
}

Review paper

\section{Zvonimir Šimić}

J. J. Strossmayer University of Osijek, Faculty of Electrical Engineering, Computer Science and Information Technology Osijek Kneza Trpimira 2b, Osijek, Croatia zvonimir.simic@ferit.hr

\section{Danijel Topić}

J. J. Strossmayer University of Osijek, Faculty of Electrical Engineering, Computer Science and Information Technology Osijek Kneza Trpimira 2b, Osijek, Croatia danijel.topic@ferit.hr

\author{
Goran Knežević \\ J. J. Strossmayer University of Osijek, \\ Faculty of Electrical Engineering, \\ Computer Science and Information Technology Osijek \\ Kneza Trpimira 2b, Osijek, Croatia \\ goran.knezevic@ferit.hr

\section{Denis Pelin} \\ J. J. Strossmayer University of Osijek, \\ Faculty of Electrical Engineering, \\ Computer Science and Information Technology Osijek \\ Kneza Trpimira 2b, Osijek, Croatia \\ denis.pelin@ferit.hr
}

\begin{abstract}
Battery technologies overview for energy storage applications in power systems is given. Lead-acid, lithium-ion, nickel-cadmium, nickel-metal hydride, sodium-sulfur and vanadium-redox flow batteries are overviewed. Description, graphical representation, advantages and disadvantages as well as technical characteristics are given for all technologies. Differences and similarities between different battery technologies are perceived. Battery technologies are considered with respect to peak shaving, load leveling, power reserve, integration of renewable energy, voltage and frequency regulation and uninterruptible power supply applications. According to technical characteristics for overviewed technologies, comparison between battery storage technologies is given through diagrams which are uniformed. Comparison is done according to specific power, specific energy, power density, energy density, power cost, energy cost, lifetime, lifetime cycles, cell voltage and battery technology efficiency.
\end{abstract}

Keywords - battery, technologies, overview, energy storage, applications, power system, characteristics

\section{INTRODUCTION}

There is a strong growth in the development of energy storage technologies, especially batteries, in the last decades. This is confirmed by the large number of available papers in which the overview of storage technologies and their applications is given. Some storage technologies are in use for a long time while other technologies are under research and development. Some technologies are widely used in commercial applications while others are used only for experimental applications.

Energy storage is important for matching electricity supply to load demand, increasing power quality and enabling renewable technologies integration [1]. Selection of suitable energy storage technology depends on power and energy capacity, the period during which energy needs to be available on the grid, costs, space required for technology placement and location in the network [2]. Power systems in the future could not be possible without storage. Pumped hydro storage was dominant throughout history, batteries are suitable for load shifting while flywheel, capacitors and superconductive inductors are suitable for voltage regulation
[3]. Batteries are an ideal technology for continuous energy storage applications, while flywheels and super capacitors are ideal for power storage applications [2]. For large scale energy storage applications, the most suitable technology is a pumped hydro because of technical maturity [4]. Batteries are the cheapest technology for different applications, flywheel is suitable for short storage periods while compressed air and pumped hydro are suitable for large scale applications [5]. In comparison to batteries and supercapacitors, using hybrid storage technologies lead to reduction of volume, weight and costs of storage systems [1].

Battery energy storage system (BESS) functionalities can be classified at different grid levels as following: generation, transmission and distribution, end-user and renewable energy sources (RES) integration [6]. Batteries are ideal for energy storage applications because of the short response time, modularity, flexible installation and short construction time. Batteries can meet the requirements of Grid-level large-scale electrical energy storage (GLEES) [7]. There are four main groups in which batteries can be classified: primary cells, secondary cells, reserve batteries and fuel cells. Secondary cells imply rechargeable batteries such as 
lead-acid batteries, alkaline batteries, lithium batteries, sodium batteries, flow batteries and other batteries [8]. There is a problem when batteries work in a hard environment, especially in low temperatures which can be overcome with implementation of specific materials, but a more acceptable solution is using the combination of existing battery technologies [9]. The weather impact on renewables, specifically photovoltaics, can be overcome with the use of energy storage systems. Battery storage technologies, unlike other storage technologies, are more suitable for renewable energy sources because of a simple and efficient way of electrical energy storing [10]. Lithium-ion and lead-acid are most suitable for RES integration applications [6]. Small scale batteries at consumption level have ability to solve photovoltaic variability problems. On the other side, for wind generation, additional optimization of a storage system is required. Designing a storage system is a complex process, but it is possible to make effective solutions for many different applications [11].

Lead-acid batteries are in use since a long time ago and all technology limits and possibilities are well known and like other battery technologies, lead-acid batteries are suitable for different grid applications [12]. Lithium-ion technology is widely used in small scale portable applications because of high power and energy and low weight but it Is expensive for large scale stationary applications [4]. Lithium-ion battery technology is mostly used in electric vehicles because of a high power and energy. Main obstacles for using lithium-ion batteries for stationary applications are battery aging and efficiency drop due to aging. There is a possibility of second use batteries for stationary applications [13]. Lithium-ion battery technology has a large potential to become one of the main technologies for grid applications because of a high efficiency, energy density and long cycle life, but to achieve this, it is required to decrease technology costs, build effective systems for collecting and recycling and develop new lithium technologies [14].

Research is focused on electrochemical storage technologies. Development of battery technologies with high efficiency and low cost is required for large scale grid applications. There are potassium-ion batteries with high energy density, but low cost in comparison to lithium-ion batteries [15]. Research and development of battery technologies in the future will be focused on solid state batteries, which are safe and have high energy density and currently used batteries with liquid electrolyte will be replaced with solid state batteries [16]. Future development of battery storage technologies is focused on improving storage system efficiency and decreasing investment cost [17]. Development of storage systems should be focused on technologies with high performance and low prices. Environmental impact of storage technologies, especially batteries, is significant [18]. There are needs for development of microgrids with energy storage systems, but using only one storage technology cannot meet all requirements of a microgrid so there is a need for development of hybrid storage technologies for microgrid applications [19]. The number of plug-in electric vehicles is constantly growing and, in the future, electric vehicles will participate as a virtual energy storage system and this can reduce the need for stationary storage [20].

This paper deals with battery storage technologies overview and their grid applications. The paper is divided into 5 chapters. Chapter 1 gives a short overview of available papers which deals with battery storage technologies. In chapter 2, six battery technologies are explained in the following order: lead-acid, lithium-ion. nickel-cadmium, nickel-metal hydride, sodium-sulfur and vanadium-redox flow batteries. In chapter 3, following grid applications are explained: peak shaving, load leveling, power reserve, integration of renewable energy, voltage and frequency regulation and uninterruptible power supply, Grid applications are presented textually and graphically. In chapter 4, comparison of battery technologies is done through diagrams according to characteristics given in the chapter 2. Chapter 5 will give conclusions about overviewed battery technologies.

This paper will give contributions through an overview of the most used battery technologies for different grid applications All technologies are overviewed in the same way, first textual description, then graphical representation, then advantages and disadvantages and the technology characteristics. One of the observed characteristics is energy and power cost which will be expressed in EUR, unlike most of the reviewed papers in which it is expressed in USD. Overviewed technologies will be compared through uniformed diagrams. In this paper, specific power and specific energy, then power density and energy density, then power and energy cost, then lifetime and the number of lifetime cycles, then cell voltage and the efficiency for battery technologies will be compared.

\section{BATTERY TECHNOLOGIES OVERVIEW}

With the development of smart grids and microgrids there is a growing need for energy storage in power systems. Throughout history various storage systems have been developed for electrical energy storage. The main difference between various storage types is in a form of energy in which electrical energy is stored. There are mechanical, thermal, thermochemical, chemical, electrochemical, electrical and magnetic storage types. Main mechanical storage technologies are flywheels, pumped hydro and compressed air. Electrical storage technologies are capacitors and supercapacitors. Main chemical storage technology are hydrogen fuel cells.

This paper deals with batteries which are an electrochemical storage technology. There are different battery technologies, and the several types will be explained. There are also flow battery technologies and 
one of them will be explained. In this paper the following battery technologies are presented:

- lead-acid,

- lithium-ion,

- nickel-cadmium,

- nickel-metal hydride,

- sodium-sulfur,

- vanadium-redox flow.

The overview of listed battery technologies is done according to different technical characteristics. Observed technical characteristics are defined below.

Cell voltage $[\mathrm{V}]$ is a voltage measured on the battery cell between positive and negative terminals. It is very important for stacking cells into batteries with previously defined voltage.

Specific energy $[\mathrm{Wh} / \mathrm{kg}]$ represents the available energy of battery technology per unit of mass. It is important for comparing the output energy of different technologies with equal mass.

Specific power [W/kg] represents the available power of battery technology per unit of mass. It is important for comparing the output power of different technologies with equal mass.

Energy density $\left[\mathrm{kWh} / \mathrm{m}^{3}\right]$ defines the available energy of battery technology per unit of volume. It is important for comparing the output energy of different technologies with equal volume.

Power density $\left[\mathrm{kW} / \mathrm{m}^{3}\right]$ defines the available power of battery technology per unit of volume. It is important for comparing the output power of different technologies with equal volume.

Efficiency [\%] shows the ratio between energy that can be discharged from battery and energy used to charge battery. There are losses during energy conversion from electrical to electrochemical and then during conversion from electrochemical to electrical.

Working temperature $\left[{ }^{\circ} \mathrm{C}\right]$ is the temperature range at which the battery technology can operate. If temperature is out of this range it can come to significant reduction of battery performance.

Lifetime cycles [cycles] represents the number of charge and discharge processes during which the battery keeps minimum working performance. It's important for applications with a lot of charging and discharging processes because there are a high number of cycles.

Lifetime [years] represents the number of years during which the battery keeps the minimum working performance. If lifetime is short, batteries need to be replaced often, which is expensive.

Maximum depth of discharge [\%] represents the amount of charge that can be discharged in one cycle. Some technologies cannot be fully discharged.
Self-discharging rate [\%] represents the amount of charge that is discharged when the battery is not in use. It is not significant if battery storage is charging and discharging all the time.

Power rating [MW] shows power capacity of installed batteries on the same location which can be considered as a single storage unit. It is important for planning large scale battery storage systems.

Energy cost $[€ / \mathrm{kWh}]$ defines the price of battery energy storage per unit of energy. Prices in EUR are converted from prices in USD.

Power cost $[€ / \mathrm{kW}]$ defines the price of battery energy storage per unit of power. Prices in EUR are converted from prices in USD. Given prices are approximate and intended only for technology comparison.

\subsection{Lead-acid}

Lead-acid (Pb-acid) technology has been in use for a long time, it is easy and cheap for installation and maintenance, so this is the main reason for wide use of this technology and this technology is also one of the most common for stationary applications worldwide. Leadacid batteries have ability to perform a deep discharge when it is required and the main problem with lead-acid batteries is that battery performance largely depends on temperature [21]. Nominal voltage of this technology cell is around 2 volts. Lead-acid battery technology is based on positive and negative electrodes submerged into electrolyte which is a combination of sulfuric acid and water, lead dioxide is used as a positive electrode and lead is used as a negative electrode [12]. Lead-acid battery technology cell is shown in Fig. 1.

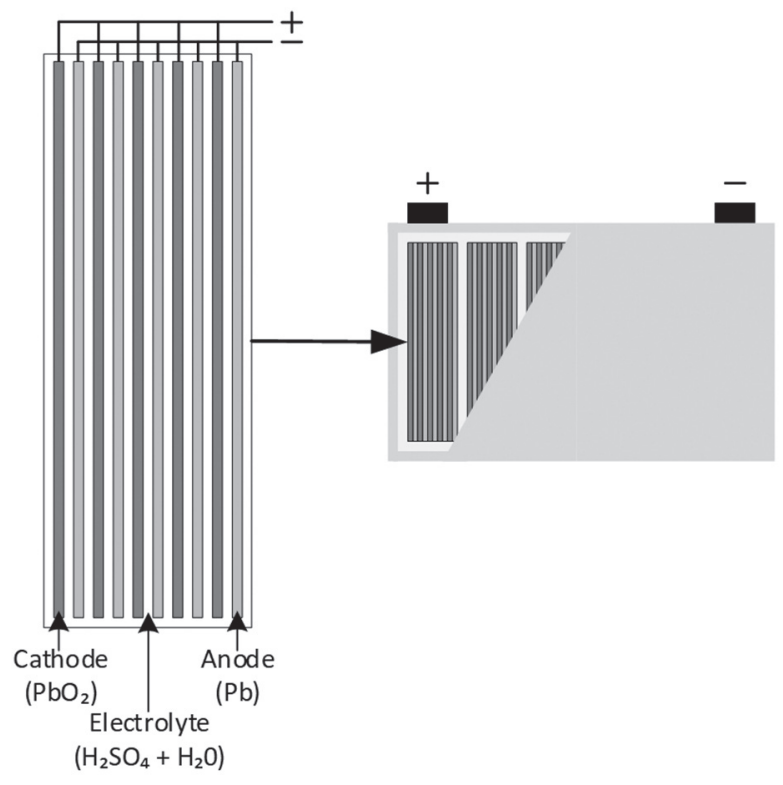

Fig. 1. Lead-acid battery cell

Some advantages of the lead-acid technology are low cost, high cell voltage, suitability for intermittent charge applications and good ability of recycling. Disadvantages are limited energy density and the number 
of lifetime cycles which is lower in comparison to other technologies [7]. Detailed characteristics of the leadacid battery technology are shown in table 1 .

Table 1. Lead-acid characteristics $[4,5,7,8,19]$

\begin{tabular}{|cc|}
\hline Characteristics & Value \\
Cell voltage & $2-2.1 \mathrm{~V}$ \\
\hline Specific energy & $25-50 \mathrm{Wh} / \mathrm{kg}$ \\
\hline Specific power & $150-400 \mathrm{~W} / \mathrm{kg}$ \\
\hline Energy density & $25-90 \mathrm{kWh} / \mathrm{m}^{3}$ \\
\hline Power density & $10-400 \mathrm{~kW} / \mathrm{m}^{3}$ \\
\hline Efficiency & $63-90 \%$ \\
\hline Working temperature & $18-45{ }^{\circ} \mathrm{C}$ \\
\hline Lifetime cycles & $250-2000$ \\
\hline Lifetime & $2-15 \mathrm{years}$ \\
\hline Max. depth of discharge & $80 \%$ \\
\hline Self-discharge rate & $0.1-0.3 \% \mathrm{per}$ day \\
\hline Power rating & $0-20 \mathrm{MW}$ \\
\hline Energy cost & $40-170 € / \mathrm{kWh}$ \\
\hline Power cost & $250-500 € / \mathrm{kW}$ \\
\hline
\end{tabular}

\subsection{Lithium-ion}

Lithium-ion (Li-ion) technology is one of the most advanced battery technologies widely used today. Cellphones, smartphones, tablets, laptops, all gadgets are powered with the Li-ion battery. There are many pros of the lithium-ion technology: high power, energy capacity, long battery lifetime and relatively low weight and because of these pros, Li-ion technology is being used to power hybrid and electric vehicles [22]. Lithium-ion battery working principle is given in Fig. 2 according to [13]. Li-ion cells consist of two electrodes, anode and cathode. Graphite is used as anode and the lithium metal oxide Is used as cathode. The lithium salt in organic solvent is used as electrolyte. Anode collector is made from copper (Cu) and cathode collector is made from aluminum (Al). Working principle of this technology is based on LI-ions moving from cathode to anode when battery is in charging process and from anode to cathode when battery is in discharging process [23].

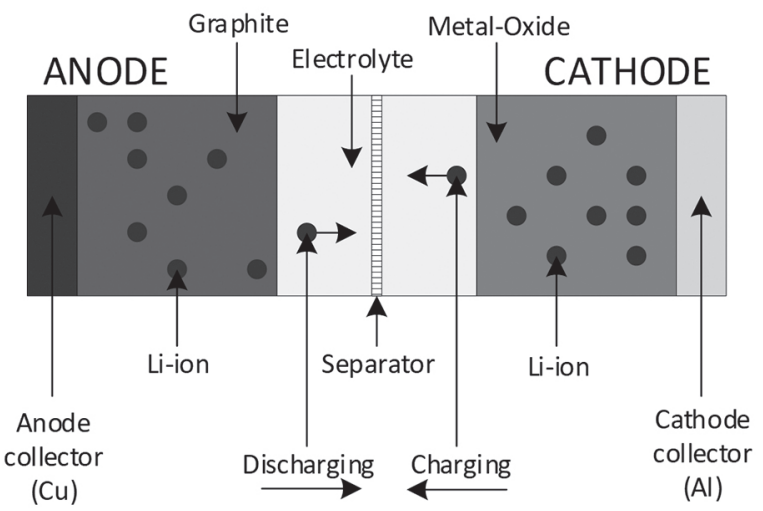

Fig. 2. Lithium-ion technology working principle
Advantages of the lithium-ion technology are long battery lifetime, the number of lifetime cycles, high energy density, low maintenance cost and there is no memory effect. Disadvantages are high cost in comparison to other technologies, poor performance at high temperature and the request for protective circuits [7]. Detailed characteristics of the lithium-ion battery technology are shown in table 2.

Table 2. Lithium-ion characteristics $[4,5,7,8,19]$

\begin{tabular}{|cc|}
\hline Characteristics & Value \\
Cell voltage & $2.5-5 \mathrm{~V}$ \\
\hline Specific energy & $80-250 \mathrm{Wh} / \mathrm{kg}$ \\
\hline Specific power & $200-2000 \mathrm{~W} / \mathrm{kg}$ \\
\hline Energy density & $95-500 \mathrm{kWh} / \mathrm{m}^{3}$ \\
\hline Power density & $50-800 \mathrm{~kW} / \mathrm{m}^{3}$ \\
\hline Efficiency & $75-97 \%$ \\
\hline Working temperature & $20-65^{\circ} \mathrm{C}$ \\
\hline Lifetime cycles & $100-10000$ \\
Lifetime & $5-15 \mathrm{years}$ \\
\hline Max. depth of discharge & $100 \%$ \\
\hline Self-discharge rate & $0.1-0.3 \% \mathrm{per} \mathrm{day}$ \\
\hline Power rating & $0-0.1 \mathrm{MW}$ \\
Energy cost & $500-2100 € / \mathrm{kWh}$ \\
Power cost & $1000-3400 € / \mathrm{kW}$ \\
\hline
\end{tabular}

\subsection{Nickel-cadmium}

Nickel-cadmium (Ni-Cd) technology is in use for a long time in applications that require a long battery life and in difficult environmental conditions because this battery technology is cheap and robust. Nickelcadmium technology is based on cathode made from nickel oxide hydroxide and anode made from metallic cadmium while electrolyte used for $\mathrm{Ni}-\mathrm{Cd}$ batteries is potassium hydroxide [24]. Cross section of the nickelcadmium battery is shown in Fig. 3 according to [4]. $\mathrm{Ni}-\mathrm{Cd}$ batteries can be charged with a high charge rate which means that the battery is charging with a current much higher than a nominal current is, but in this case the charging process must be stopped when the battery is full, otherwise the battery will heat very fast which leads to damage. The main problem with $\mathrm{Ni}-\mathrm{Cd}$ batteries is a memory effect which means that battery loses full capacity if it is slightly discharging and recharging every time during a certain period [25].

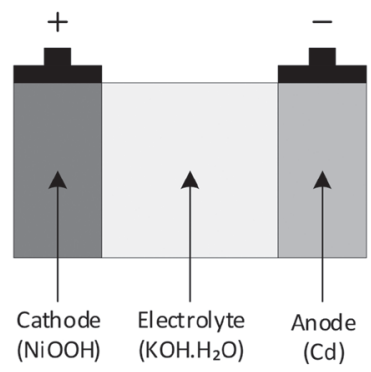

Fig. 3. Nickel-cadmium battery cross section 
Advantages of $\mathrm{NiCd}$ technology are low maintenance cost, the number of lifetime cycles, suitability for longterm storage and ability to resist electrical and physical stress. Disadvantages are high cost in comparison to the lead-acid technology, limited energy density, toxic and caustic elements in batteries and the memory effect [7]. Detailed characteristics of NiCd battery technology are shown in table 3.

Table 3. NiCd characteristics $[4,5,7,8,19]$

\begin{tabular}{|cc}
\hline Characteristics & Value \\
\hline Cell voltage & $1.2-1.3 \mathrm{~V}$ \\
\hline Specific energy & $30-80 \mathrm{Wh} / \mathrm{kg}$ \\
\hline Specific power & $80-300 \mathrm{~W} / \mathrm{kg}$ \\
\hline Energy density & $15-150 \mathrm{kWh} / \mathrm{m}^{3}$ \\
\hline Power density & $40-140 \mathrm{~kW} / \mathrm{m}^{3}$ \\
\hline Efficiency & $60-90 \%$ \\
\hline Working temperature & $-40-50{ }^{\circ} \mathrm{C}$ \\
\hline Lifetime cycles & $1000-5000$ \\
\hline Lifetime & $10-20 \mathrm{years}$ \\
\hline Max. depth of discharge & $80 \%$ \\
\hline Self-discharge rate & $0.2-0.6 \% \mathrm{per} \mathrm{day}$ \\
\hline Power rating & $0-40 \mathrm{MW}$ \\
\hline Energy cost & $680-1300 € / \mathrm{kWh}$ \\
\hline Power cost & $420-1300 € / \mathrm{kW}$ \\
\hline
\end{tabular}

\subsection{Nickel-metal hydride}

Nickel-metal hydride (Ni-MH) technology has been used in several applications such as energy storage for smart energy systems, robust battery systems which work at high temperatures, hybrid electric cars and public transport [26]. Ni-MH battery cell cross section with the main parts is shown in Fig. 4 according to [27]. Nickel-metal hydride technology is based on the negative electrode made from hydrogen-absorbing alloys which have the possibility to absorb releasing hydrogen and the positive electrode made from nickel oxyhydroxide. There is a separator which separates positive and negative electrodes to prevent shorting between electrodes. Electrolyte used in this technology is potassium hydroxide $(\mathrm{KOH})$. There is a current collector made of metal which minimizes the internal battery resistance. To release gases produced during the overcharging or shorting there is a self-sealing safety vent [28].

Some advantages of $\mathrm{NiMH}$ technology are long battery lifetime, high number of lifetime cycles, good performance at the high temperatures, high energy density, good ability of recycling and the high tolerance to battery overcharging and over discharging. Disadvantages are high cost in comparison to the lead-acid technology and bad performance at the low working temperatures [7]. Detailed characteristics of NiMH battery technology are shown in table 4.

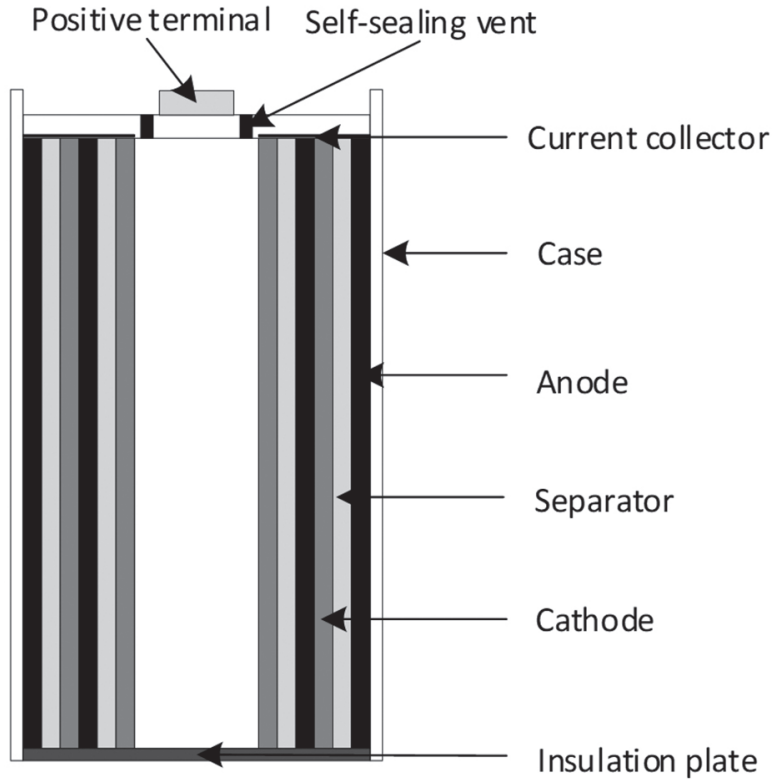

Fig. 4. Nickel-metal hydride battery cross section

Table 4. NiMH characteristics $[4,5,7,8,19]$

\begin{tabular}{|cc|}
\hline Characteristics & Value \\
\hline Cell voltage & $1.2-1.35 \mathrm{~V}$ \\
\hline Specific energy & $40-110 \mathrm{Wh} / \mathrm{kg}$ \\
\hline Specific power & $200-300 \mathrm{~W} / \mathrm{kg}$ \\
\hline Energy density & $40-300 \mathrm{kWh} / \mathrm{m}^{3}$ \\
\hline Power density & $10-600 \mathrm{~kW} / \mathrm{m}^{3}$ \\
\hline Efficiency & $50-80 \%$ \\
\hline Working temperature & $-30-70{ }^{\circ} \mathrm{C}$ \\
\hline Lifetime cycles & $300-1800$ \\
\hline Lifetime & $2-15$ years \\
\hline Max. depth of discharge & $100 \%$ \\
\hline Self-discharge rate & $5-20 \% \mathrm{per} \mathrm{day}$ \\
\hline Power rating & $0.01-3 \mathrm{MW}$ \\
\hline Energy cost & $170-640 € / \mathrm{kWh}$ \\
\hline Power cost & $200-470 € / \mathrm{kW}$ \\
\hline
\end{tabular}

\subsection{Sodium-sulfur}

Sodium-sulfur (NaS) battery technology is one of the most suitable for use in energy storage systems because of the high energy density [29]. NaS battery cell cross section is shown in Fig. 5 according to [29]. This technology is based on the use of sodium as anode and sulfur as cathode, electrolyte is beta alumina ceramics. For this technology is interesting that electrolyte is also a separator. NaS technology has a low internal cell resistance because of the use a ceramic electrolyte and this is good for two reasons. With the low resistance, power to weight ratio is being increased and heat produced during the charging process is being decreased [30]. Typically working temperature of the sodium-sulfur 
batteries is between $300^{\circ} \mathrm{C}$ and $350^{\circ} \mathrm{C}$. Reason for high temperature is to keep electrodes in a liquid state. High temperature decreases efficiency of the cycle which increases the number of operation cycles. [31]

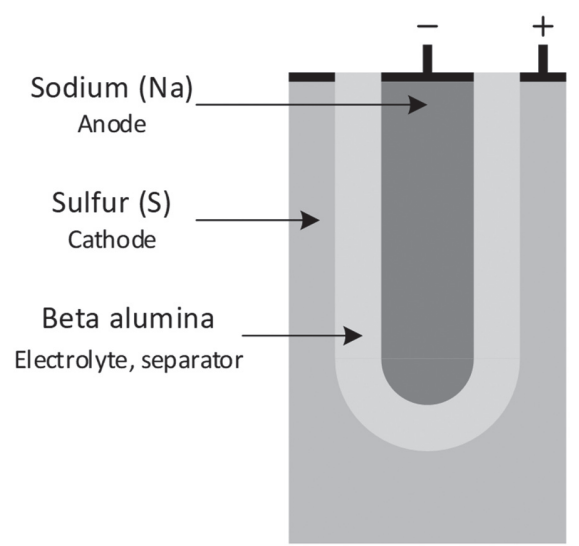

Fig. 5. Sodium-sulfur battery cell cross section

Advantages of sodium-sulfur technology are high energy density, high number of lifetime cycles, capability of pulse power and good resistivity to self-discharging. Disadvantages are high cost and high temperature required for battery operation [7]. Detailed characteristics of sodium-sulfur battery technology are shown in table 5 .

Table 5. NaS characteristics $[4,5,7,8,19]$

\begin{tabular}{cc}
\hline Characteristics & Value \\
Cell voltage & $1.8-2.71 \mathrm{~V}$ \\
\hline Specific energy & $150-240 \mathrm{Wh} / \mathrm{kg}$ \\
\hline Specific power & $90-230 \mathrm{~W} / \mathrm{kg}$ \\
\hline Energy density & $150-350 \mathrm{kWh} / \mathrm{m}^{3}$ \\
\hline Power density & $1.2-50 \mathrm{~kW} / \mathrm{m}^{3}$ \\
\hline Efficiency & $75-90 \%$ \\
\hline Working temperature & $300-350{ }^{\circ} \mathrm{C}$ \\
\hline Lifetime cycles & $2500-40000$ \\
\hline Lifetime & $10-15$ years \\
\hline Max. depth of discharge & $100 \%$ \\
\hline Self-discharge rate & $0 \%$ per day \\
\hline Power rating & $0.05-34 \mathrm{MW}$ \\
\hline Energy cost & $250-420 € / \mathrm{kWh}$ \\
\hline Power cost & $850-2500 € / \mathrm{kW}$ \\
\hline & \\
\hline & \\
\hline &
\end{tabular}

\subsection{Vanadium-redox flow battery}

Vanadium-redox flow battery (VRFB) is a new technology which promises a lot because of the very good characteristics. This technology has a long lifetime, very fast response time and long storage time which is ideal for long-term energy storage. Power and energy of VRFB are independent, power depends on the number and size of the cells and energy depends on the available electrolyte, respectively tank size [32]. Work- ing principle of the VRFB technology is shown in Fig. 6 according to [33]. VRFB technology is based on two tanks in which vanadium ions electrolytes are stored, one electrolyte is positive and the other is negative. Flow of electrons is caused by oxidation and reduction processes in the ion selective membrane through which electrolytes are being pumped. Response time of this technology is fast because electrolyte flow does not change, regardless of whether battery is charging or discharging [33].

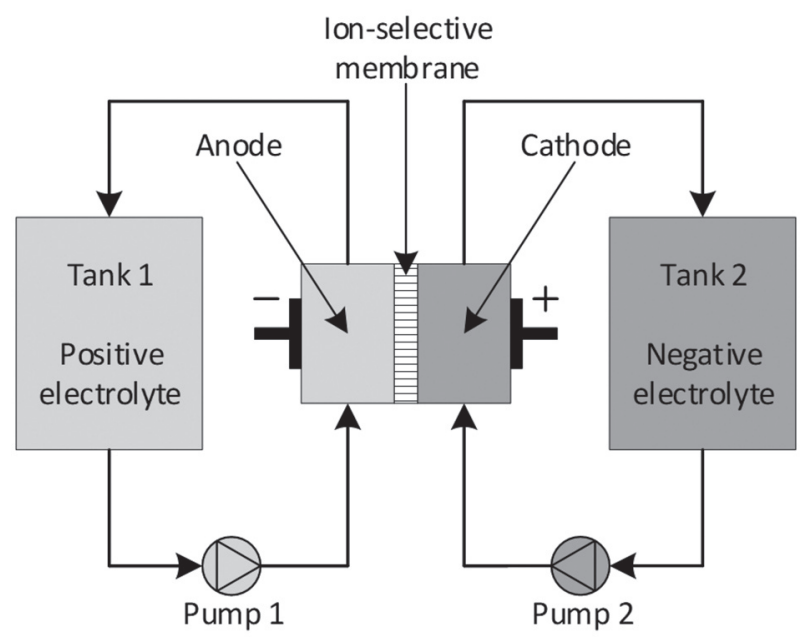

Fig. 6. Vanadium-redox flow battery working principle

Advantages of the vanadium-redox flow battery technology are high operating safety, high number of lifetime cycles, low operation and maintenance cost and deep discharging capability. Disadvantages are low energy density and the large space required for technology placement [7]. Detailed characteristics of the vanadium-redox flow battery technology are shown in table 6.

Table 6. VRFB characteristics $[4,5,7,8,19]$

\begin{tabular}{|cc|}
\hline Characteristics & Value \\
\hline Cell voltage & $1.2-1.4 \mathrm{~V}$ \\
\hline Specific energy & $10-130 \mathrm{Wh} / \mathrm{kg}$ \\
\hline Specific power & $50-150 \mathrm{~W} / \mathrm{kg}$ \\
\hline Energy density & $10-33 \mathrm{kWh} / \mathrm{m}^{3}$ \\
\hline Power density & $2.5-33 \mathrm{~kW} / \mathrm{m}^{3}$ \\
\hline Efficiency & $75-90 \%$ \\
\hline Working temperature & $5-45^{\circ} \mathrm{C}$ \\
\hline Lifetime cycles & $10000-16000$ \\
\hline Lifetime & $5-15$ years \\
\hline Max. depth of discharge & $100 \%$ \\
\hline Self-discharge rate & $0 \%$ per day \\
\hline Power rating & $0.03-3 \mathrm{MW}$ \\
\hline Energy cost & $130-850 € / \mathrm{kWh}$ \\
\hline Power cost & $500-1300 € / \mathrm{kW}$ \\
\hline
\end{tabular}




\section{GRID APPLICATIONS OF A BATTERY STORAGE}

With growth of the amount of distributed generation, passive distribution grids become active. It means that energy flows are in two ways, from generation, over transmission grid to distribution grid and in the opposite way, from distribution grid to transmission grid. Operation of an active distribution grid is more complicated then operation of a passive grid, especially if distributed generation is intermittent, such as photovoltaic and wind. There is a demand for additional energy storage which has ability to support grid functionality and stability. In conventional power systems, load profile is divided on a base load, which is covered from baseload power plants and on a variable load, which is covered from load following power plants. Variable load can be partially covered from energy storage so there is less need for regulation power plants. Batteries are more acceptable for voltage and frequency regulation application than regulation power plants because of the fast response on voltage and frequency changes. Batteries are being used in the following grid applications:

- peak shaving,

- load leveling,

- power reserve,

- integration of renewable energy sources,

- voltage and frequency regulation,

- uninterruptible power supply.

\subsection{Peak shaving}

Highest demand for electrical energy appears in the evening during winter because of the high amount of energy is required for heating and in the middle of the day during summer because of the high amount of energy is required for cooling. Grid utility operators have introduced different prices of electricity depending on energy demand. When demand is high, price is higher and when demand is low, price is lower. Methods for reducing consumption of electrical energy when demand is at peak are called the peak shaving and it can be done in different ways. First method is switching off appliances that are not in use and installing heating systems with thermostat to reduce power demand, second method requires the installation of additional generators to achieve peak power demand and third method is using batteries to cover consumption during peak power demand [16].

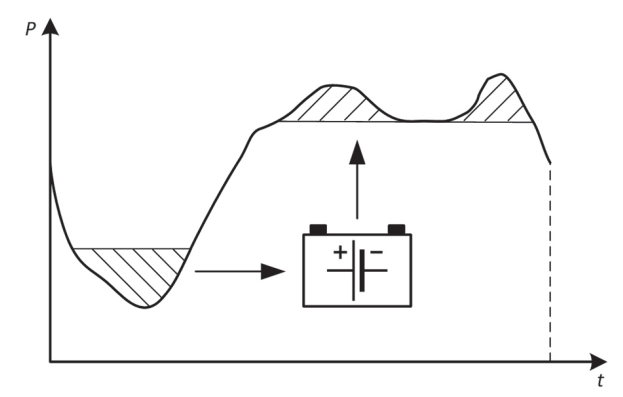

Fig. 7. Peak shaving with using of a battery storage
Peak shaving with the use of a battery storage is shown in Fig. 7. When the power demand is low, energy price is also low, and energy can be stored in batteries and when the power demand is high, energy price is also high and peak load can be partially or fully covered with energy from batteries [18].

\subsection{Load leveling}

Load leveling is not much different from peak shaving. Booth applications have similar working principles. Energy is being stored in batteries during low power demand and being used from batteries during high power demand. Peak shaving has a task to level the load profile only during peak power demand while load leveling has a task to level the entire load profile during the entire day [18]. Load leveling uses low price energy from base generation to cover high price peak energy demand. Like the peak shaving, load leveling can give profit to the customers, because the use of stored energy during high price periods and make customers less dependent on the electricity market during peak periods [34]. Load leveling with the use of a battery storage is shown in Fig. 8 .

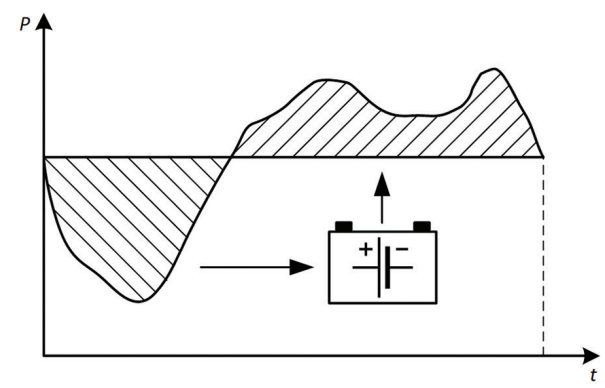

Fig. 8. Load leveling with using of a battery storage

It can be assumed that load leveling requires much higher battery capacity than peak shaving applications because peak shaving is covering consumption during only a few hours a day while load leveling is covering consumption more hours a day.

\subsection{POWER RESERVE}

When grid operators predict the load demand for the day ahead it can happen that actual load demand is less than predicted load demand and it also can happen that actual load demand is higher than predicted. There is a possibility to install a battery storage system that will store energy excess when the actual load demand is less than predicted and cover actual load demand when it is higher than predicted load demand as shown in Fig. 9. Battery storage systems are ideal for this application because of the fast response time [16].

Reserve in the power system is important because reserve supports the power system from the unaware load reducing when load demand is high. Battery storage is a much better solution for spinning reserve than synchronous generators which must be synchronized with the grid during startup and this makes them slow. 
More reserve capacity leads to better system reliability, but it is necessary to find the optimal reserve capacity due to high installation price. In the future, electric vehicles connected to the charging stations will also be able to provide reserve in the power system [18]. Providing a reserve service to the grid operator has a financial benefit for battery storage owners. Grid operators and reserve providers enter a contract that defines the amount of energy which must be available to feed into the power system and the energy price at which the operator will buy energy from the reserve provider.

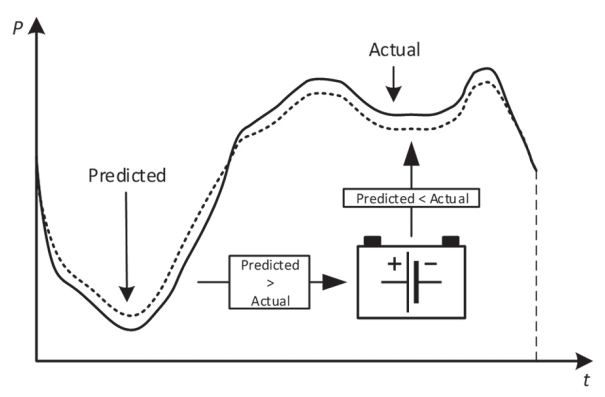

Fig. 9. Battery power reserve

\subsection{Integration of renewable energy sources}

Renewable energy sources nowadays are present worldwide and their share in total production of electrical energy is in constant growth. Integration of renewable energy sources, especially wind and solar, causes economical and technical challenges for grid operators [5]. Renewable energy sources are variable, intermittent and unpredictable so they are harder to integrate in the power system [35]. It is more difficult to operate the power system and keep stability because of power fluctuations [36]. Intermittency and variability of the renewable energy sources are primarily caused by weather changes. In the case of photovoltaics, it often happens that clouds reduce solar radiation which leads to decreased generation from photovoltaics. In the case of wind power, wind speed is variable which leads to constant variability in generation from wind.

Intermittency and variability can be compensated with implementation of a battery storage system which is necessary for the off-grid photovoltaic and wind power. On the other side, for on-grid photovoltaic and wind power, a battery storage is welcome because it allows integration of higher amounts of distributed generation. During power outages caused by weather changes consumption can be covered from energy stored in batteries which are distributed in the power system. As the amount of distributed generation will be increased, capacity of installed battery storage also needs to be increased because for higher amounts of solar and wind generation, more battery storage will be needed to cover consumption during power outages. Fig. 10. shows the case in which energy excess produced from photovoltaic during sunny days can be used later in the evening to cover higher energy demand.

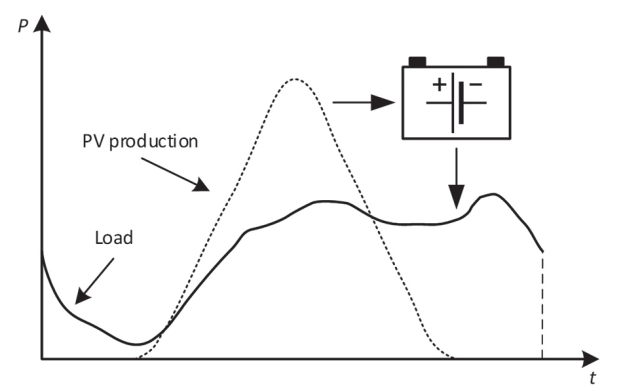

Fig. 10. Photovoltaic with a battery storage

\subsection{Voltage and frequency regulation}

In the power system it is required to maintain voltage and frequency to keep the power system stability. Voltage is regulated with the reactive power and frequency is regulated with the active power. Voltage and frequency changes in power systems with integrated renewables are more significant and occur more often so there is a need for advanced voltage and frequency regulation systems [37].

Grid voltage should be maintained within defined value range at consumption level. Grid voltages, out of range, may cause some electrical devices malfunction or even damage [37]. If voltage is lower than the nominal value, injection of the reactive power is required and if voltage is higher than the nominal value, absorption of the reactive power is required. In conventional power systems voltage regulation is done by static or synchronous compensation which injects reactive power in the grid when needed. There is ability to install the battery storage which can absorb reactive power to decrease voltage when voltage is high and inject the additional reactive power to increase voltage when voltage is low.

Frequency in grid should be maintained within defined value range and it can be done with balance between load and power generation [38]. When load power is higher than generated power, frequency is lower than the nominal value and injection of the additional active power in grid is required. When generated power is higher than load power, frequency is higher than the nominal value and decrease of generated power or increase of load power is required. In conventional power systems frequency regulation is done by increasing or decreasing generator output power. There is an ability to install a battery storage which can absorb power excess from the grid to decrease frequency when it is too high and inject power to the grid to increase frequency when it is too low.

\subsection{Uninterruptible power supply}

Uninterruptible power supplies (UPS) have a task to supply electrical and electronic equipment with constant power during power outages or state of emergency. UPS are usually used in the critical applications where the main power supply interruption, even for a 
short time, can have serious, or even dangerous, consequences [39]. Critical applications are: control and monitoring systems in substations, power plants and industrial facilities, emergency lighting, medical equipment, computer systems, data centers, telecommunication systems and base stations, airports, lighting and signalization in tunnels, etc.

Main parts of a typical UPS system are battery bank, rectifier, inverter and static switch [40]. Battery banks have a task to store electrical energy which will be used during power outages, lead-acid technology was usually used and now, lithium-ion technology is often in use. Rectifiers are used to connect AC grids with DC batteries and enable to charging batteries with energy from the grid. Inverter is used to connect DC batteries with AC load and enable to supply load with energy from batteries. Static switch has a task to bypass converters when the rectifier or inverter are not working and enable to power load with energy directly from the grid.

\section{BATTERY TECHNOLOGY COMPARISON}

Comparison of overviewed battery technologies is done according to technical characteristics given in table $1-6$. Comparison of characteristics is given through following six diagrams which are uniformed for better technology comparison. The first four diagrams are two-dimensional, one technology characteristic is shown on $\mathrm{x}$-axis while another is showed on $y$-axis. The last two diagrams are one-dimensional, battery technologies are shown on $\mathrm{x}$-axis while technology characteristic is shown on y-axis.

Diagram which shows specific power and specific energy for different battery storage technologies is presented in Fig. 11. Lead-acid, nickel-cadmium, nickel-metal hydride and vanadium-redox flow battery have the low specific power and specific energy. Sodium-sulfur technology has the low specific power, but the high specific energy, from 150 to $240 \mathrm{Wh} / \mathrm{kg}$. For the lithium-ion battery technology, specific energy is from 80 to $250 \mathrm{Wh} / \mathrm{kg}$ and specific power is from 200 to $2000 \mathrm{~W} / \mathrm{kg}$, which is more than other technologies.

Diagram which shows power density and energy density for different battery storage technologies is presented in Fig. 12. Vanadium-redox flow battery has very low power density, from 2.5 to $3 \mathrm{~kW} / \mathrm{m}^{3}$ and very low energy density, from 10 to $33 \mathrm{kWh} / \mathrm{m}^{3}$. It is because a large space needed for two electrolyte tanks placement. For li-ion technology, energy density is from 95 to $500 \mathrm{kWh} / \mathrm{m}^{3}$ and power density is from 50 to $800 \mathrm{~kW} / \mathrm{m}^{3}$, which is more than other technologies.

Diagram which shows power cost and energy cost for different battery storage technologies is presented in Fig. 13. Most expensive battery technology is lithiumion with power cost from 1000 to $3400 € / \mathrm{kW}$ and energy cost from 500 to $2100 € / \mathrm{kWh}$. Battery technology with the lowest price is lead-acid with power cost from 250 to $500 € / \mathrm{kW}$ and energy cost from 40 to $170 € / \mathrm{kWh}$.

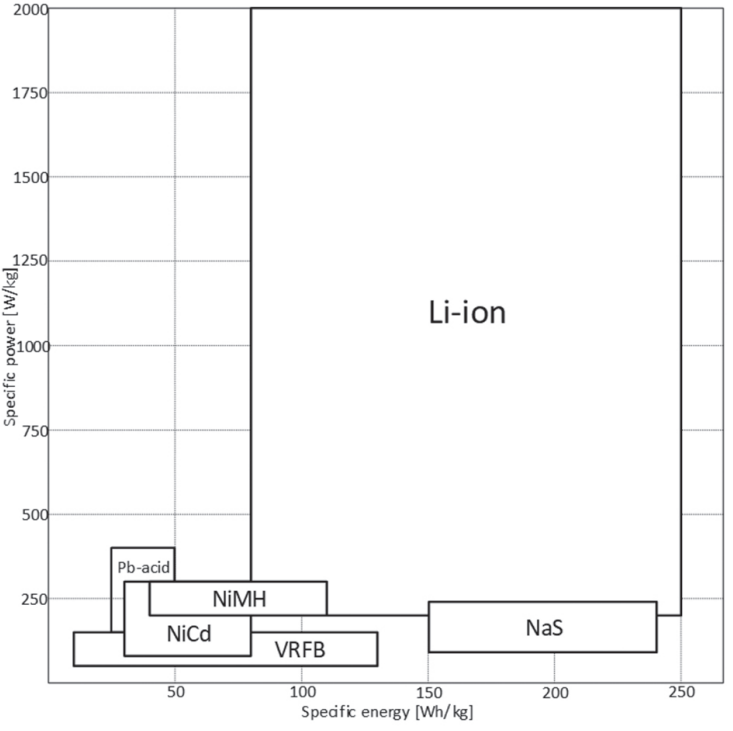

Fig. 11. Specific power to specific energy

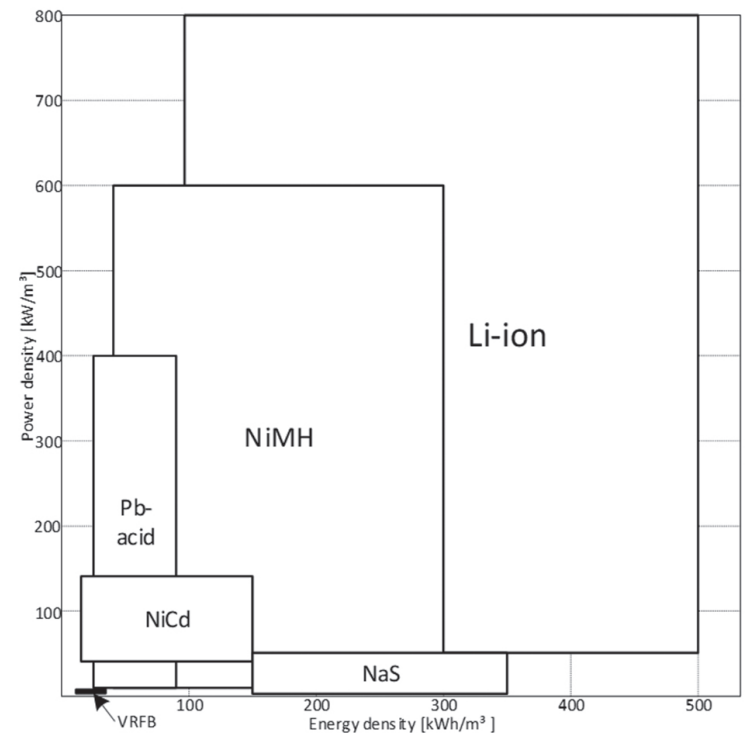

Fig. 12. Power density to energy density

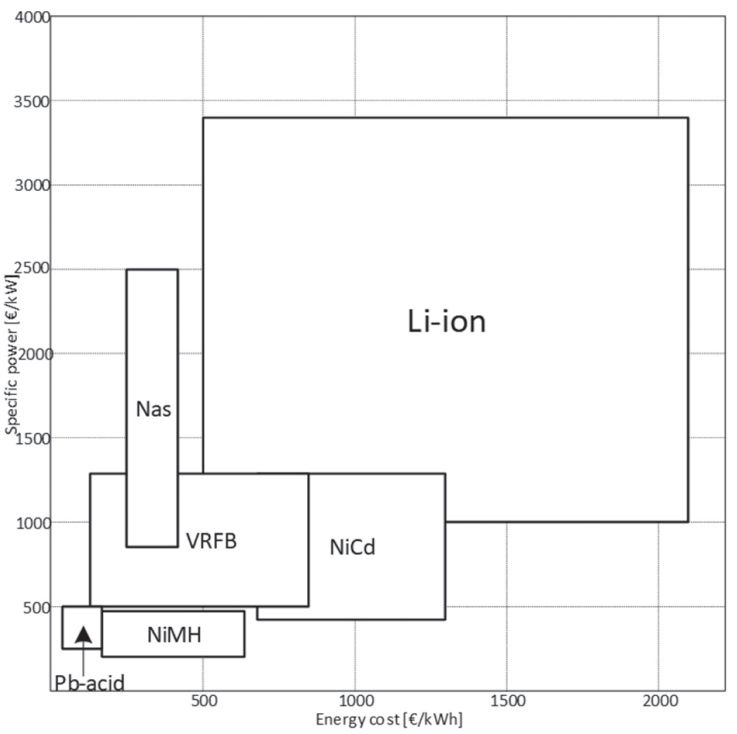

Fig. 13. Cost of battery technologies 
A diagram which shows the lifetime of battery technologies is presented in Fig. 14. Lifetime for the lithiumion is from 5 to 15 years and the number of lifetime cycles is from 1000 to 10000 . Nickel-cadmium battery technology has the longest lifetime, from 10 to 20 years. Sodium-sulfur battery technology has the greatest number of lifetime cycles, from 2500 to 40000.

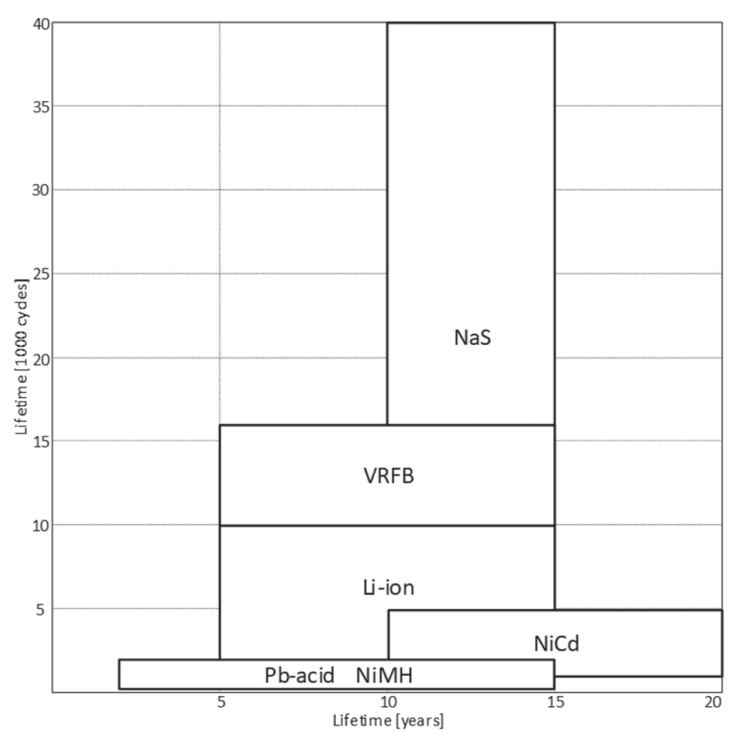

Fig. 14. Lifetime of battery technologies

Fig. 15 shows cell voltage for different battery technologies. Nickel-cadmium, nickel-metal hydride and vanadium-redox flow battery have lowest cell voltage. Sodium-sulfur and lead-acid have some higher cell voltage, Highest cell voltage has the lithium-ion technology, from 2.5 to $5 \mathrm{~V}$.

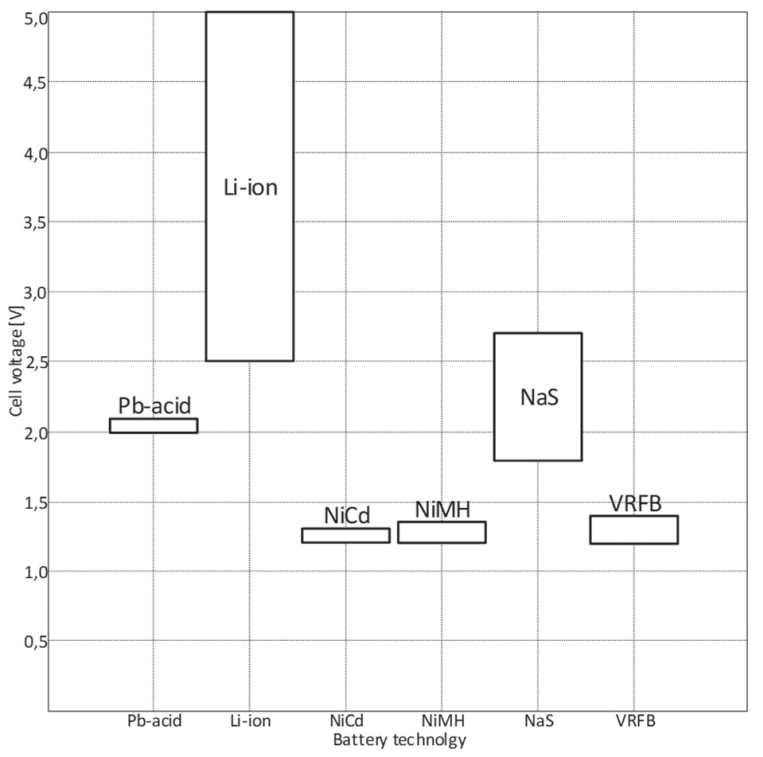

Fig. 15. Cell voltage of battery technologies

Fig. 16 shows efficiency of different battery technologies. Nickel-metal hydride has lowest efficiency, from 50 to $80 \%$. Highest efficiency is of the lithium-ion technology, from 75 to $97 \%$.

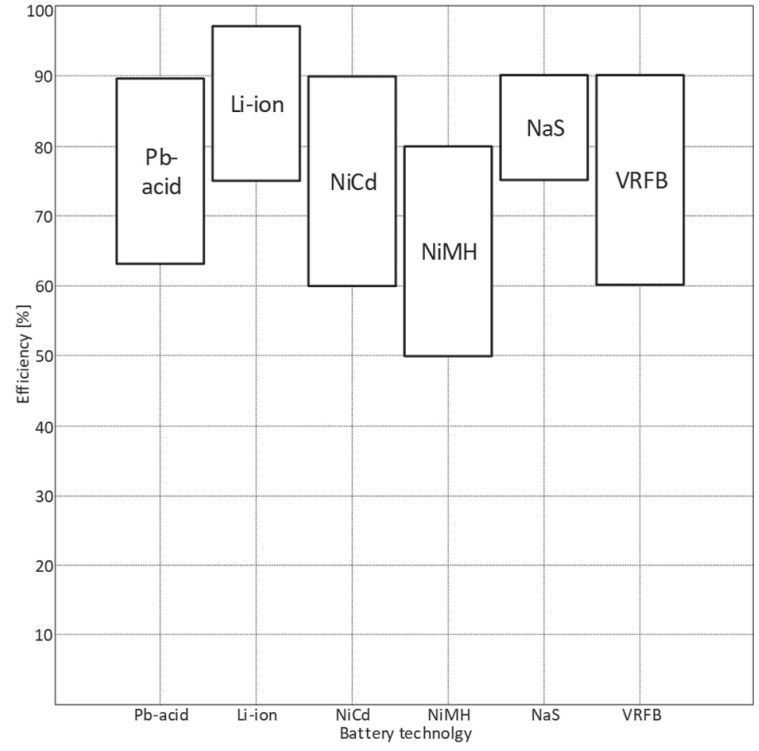

Fig. 16. Efficiency of battery technologies

According to diagrams in Fig. $11-16$, the overall table of compared technology characteristics is given. Table shows overall comparison between overviewed battery technologies according to most important technical characteristics. Through diagrams, ten battery technical characteristics are compared as follows: specific energy and specific power, energy density and power density, energy cost and power cost, lifetime and lifetime cycles, cell voltage and the last, efficiency. Values in the overall table are shown in grayscales. The best technology characteristics are shown in a darker shade and the worst technology characteristics are shown in a lighter shade.

\section{CONCLUSIONS}

In this paper, six battery technologies, that are most often used for grid applications, are overviewed. Main characteristics of the lead-acid, lithium-ion, nickelcadmium, nickel-metal hydride, sodium-sulfur and vanadium-redox flow batteries are presented and their characteristics are compared. It cannot be concluded that one technology is better than others. Some battery technologies are suitable for different applications while others have a specific application in which they have proved very good. All battery technologies are good for implementation in moderate climate conditions but only few technologies can withstand implementation in extreme climate conditions.

Lead-acid is in use for a long time and the main advantage of this technology is the very low price. Leadacid technology is suitable for different stationary applications because of good efficiency and the high cell voltage. But lead-acid battery technology has the low number of lifetime cycles. Lithium-ion is now the most advanced and the most used battery technology. According to the overall table, lithium-ion battery technology is the most suitable for different applications because of highest specific power and energy, highest 
Table 7. Comparison of battery technologies

\begin{tabular}{|c|c|c|c|c|c|c|}
\hline Characteristics & Pb-acid & Li-ion & NiCd & NiMH & NaS & VRFB \\
\hline Specific energy [Wh/kg] & $25-50$ & $80-250$ & $30-80$ & $40-110$ & $150-240$ & $10-130$ \\
\hline Specific power [W/kg] & $150-400$ & $200-2000$ & $80-300$ & $200-300$ & $90-230$ & $50-150$ \\
\hline Energy density $\left[\mathrm{kWh} / \mathrm{m}^{3}\right]$ & $25-90$ & $95-500$ & $15-150$ & $40-300$ & $150-350$ & $10-33$ \\
\hline Power density $\left[\mathrm{kW} / \mathrm{m}^{3}\right]$ & $10-400$ & $50-800$ & $40-140$ & $10-600$ & $1.2-50$ & $2.5-33$ \\
\hline Energy cost $[€ / \mathrm{kWh}]$ & $40-170$ & $500-2100$ & $680-1300$ & $170-640$ & $250-420$ & $130-850$ \\
\hline Power cost $[€ / \mathrm{kW}]$ & $250-500$ & $1000-3400$ & $420-1300$ & $200-470$ & $850-2500$ & $500-1300$ \\
\hline Lifetime [years] & $2-15$ & $5-15$ & $10-20$ & $2-15$ & $10-15$ & $5-15$ \\
\hline Lifetime cycles [cycles] & $250-2000$ & $100-10000$ & $1000-5000$ & $300-1800$ & $2500-40000$ & $10000-16000$ \\
\hline Cell voltage [V] & $2-2.1$ & $2.5-5$ & $1.2-1.3$ & $1.2-1.35$ & $1.8-2.71$ & $1.2-1.4$ \\
\hline Efficiency [\%] & $63-90$ & $75-97$ & $60-90$ & $50-80$ & $75-90$ & $75-90$ \\
\hline
\end{tabular}

power and energy density, highest cell voltage and highest efficiency. But lithium-ion battery technology has the highest price in comparison to other technologies.

Nickel-cadmium is good because of the ability of operation in extreme conditions with very low and high temperatures, but because of bad environmental impact, nickel-cadmium is replaced with the nickel-metal hydride technology. For extremely cold and hot working conditions, the most suitable technology is nickelmetal hydride. It has relatively high power and energy density and low price, but with some lower efficiency.

For applications that require a high number of lifetime cycles, the most suitable technology is sodiumsulfur because of the high number of lifetime cycles. Sodium-sulfur battery technology has high specific energy and energy density, high cell voltage and good efficiency. Main disadvantage of sodium-sulfur technology is the high working temperature.

Vanadium-redox flow batteries are future storage technology with the ability of long-time energy storage, VRFB technology has the high number of lifetime cycles. Main disadvantages of this technology are very low energy and power density and large space required for battery placement.

\section{ACKNOWLEDGEMENT}

This work was funded by the European Union through the European Regional Development Fund's Operational Programme Competitiveness and Cohesion under project KK.01.1.1.04.0034 Connected Stationary Battery Energy Storage.

\section{REFERENCES}

[1] X. Zhou, Y. Lin, Y. Ma, "The Overview of Energy Storage Technology", Proceedings of the International Conference on Mechatronics and Automation, Bejing, China, 2-5 August 2015, pp. 43-48.

[2] I. Hadjipaschalis, A. Poullikkas, V. Efthimiou, "Overview of current and future energy storage technologies for electric power applications", Renewable and Sustainable Energy Reviews, Vol. 13, No. 6-7, 2009, pp. 1513-1522.

[3] L. Branders, D. Sprake, Y. Vagapov, H. Tun, "Analysis of Electrical Energy Storage Technologies for Future Electric Grid", Proceedings of the IEEE NW Russia Young Researchers in Electrical and Electronic Engineering Conference, St. Petersburg, Russia, 2-3 February 2016, pp. 513-518. 
[4] P. Nikolaidis, A. Poullikkas, "A comparative review of electrical energy storage systems for better sustainability", Journal of Power Technologies, Vol. 97, No. 3, 2017, pp. 220-245.

[5] S. K. Fayegh, M.A.Rosen, "A review of energy storage types, applications and recent developments", Journal of Energy Storage, Vol. 27, 2020.

[6] A. Saez-de-lbarra, A. Milo, H. Gaztañaga, I. Etxeberria-Otadui, P. Rodriguez, S. Bacha, V. Debusschere, "Analysis and Comparison of Battery Energy Storage Technologies for Grid Applications", Proceedings of the IEEE Grenable Conference, Grenoble, France, 16-20 June 2013.

[7] X. Fan, B. Liu, J. Liu, j. Ding, X. Han, Y. Deng, X. Lv, Y. Xie, B. Chen, W. Hu, C. Zhong, "Battery Technologies for Grid Level Large Scale Electrical Energy", Transaction of Tianjin University, Vol. 26, No. 2, 2020, pp. 92-103.

[8] M. Morris, S. Tosunoglu, "Comparison of rechargable battery technologies", Proceedings of the ASME Early Career Technical Conference, Atlanta, Georgia, USA, 2-3 November 2012.

[9] Y. Cho, H. A. Gabbar, "Review of energy storage technologies in harsh environment", Safety in Extreme Environments, Vol. 1, 2019, pp. 11-25.

[10] E. O. Ogunniyi, H. Pienaar, “Overview of Battery Energy Storage System Advancement for Renewable (Photovoltaic) Energy Applications", Proceedings of the International Conference on the Domestic Use of Energy, Cape Town, South Africa, 4-5 April 2017.

[11] N. Ertugul, "Battery Storage Technologies, Applications and Trend in Renewable Energy", Proceedings of the IEEE International Conference on Sustainable Energy Technologies, Hanoi, Vietnam, 14-16 November 2016, pp. 420-425.

[12] G. J. May, A. Davidson, B. Monahov, "Lead batteries for utility energy storage: A review", Journal of Energy Storage, Vol. 15, 2018, pp. 145-157.

[13] H. C. Hesse, M. Schimpe, D. Kucevic, A. Jossen, "Lithium-Ion Battery Storage for the Grid-A Review of Stationary Battery Storage System Design Tailored for Applications in Modern Power Grids", Energies, Vol. 10, No. 12, 2017.
[14] T. Chen, Y. jin, H. Lv, A. Yang, M. Liu, B. Chen, Y. Xie, Q. Chen, "Applications of Lithium Ion Batteries in Grid Scale Energy Storage Systems", Transactions of Tianjin University, Vol. 26, No. 3, 2020, pp. 208-217.

[15] Z. Xio, L. Du, X. Lv, Q. Wang, J. Huang, T. Fu, S. Li, "Evaluation and Analysis of Battery Technologies Applied to Grid Level Energy Storage Systems Based on Rough Set Theory", Transactions of Tianjin University, Vol. 26, 2020, pp. 228-235.

[16] M. Sufyan, N. A. Rahim, M. M. Aman, C. K. Tan, S. R. Raihan, S. R. S. Raihan, "Sizing and applications of battery energy storage technologies in smart grid system: A review", Journal of Renewable and Sustainable Energy, Vol. 11, No. 1, 2019, p. 014105.

[17] S. O. Masebinu, E. T. Akinlabi, E. Muzenda, A. O. Aboyade, C. Mbohwa, "A Review on Battery Technologies for Electrical Energy Storage", Proceedings of the International Conference on Industrial Engineering and Operations Management, Rabat, Morocco, 11-13 April 2017, pp. 5711-5719.

[18] L. Chang, W. Zhang, S. Xu, K. Spence, "Review on Distributed Energy Storage Systems for Utility Applications", CPSS Transactions on Power Electronics and Applications, Vol. 2, No. 4, 2017, pp. 267-276.

[19] W. Xin, L. Yun, "Analysis of Energy Storage Technology and Their Application for Micro Grid", Proceedgins of the International Conference on Computer Technology, Electronics and Communication, Sanya, China, 19-21 December 2017, pp. 972-975.

[20] D. U. Sauer, M. Kleimaier, W. Glaunsinger, "Relevance of energy storage in future distribution networks with high penetration of renewable energy sources", Proceedings of the $20^{\text {th }}$ International Conference on Electricity Distribution, Prague, 8-11 June 2009.

[21] H. Keshan, J. Thornburg, T. S. Ustun, "Comparison of lead-acid and lithium ion batteries for stationary storage in off-grid energy systems", Proceedings of the $4^{\text {th }}$ Clean Energy and Technology Conference, Kuala Lumpur, Malaysia, 14-15 November 2016, pp. 1-7.

[22] D. Deng, "Li-ion batteries: basics, progress, and challenges", Energy Science \& Engineering, Vol. 3, No. 5, 2015, pp. 385-418. 
[23] B. Scrosati, J. Garche, "Lithium batteries: Status, prospects and future", Journal of Power Sources, Vol. 195, No. 9, 2009, pp. 2419-2430.

[24] R. Kasim, A. R. Abdullah, N. A. Selemat, M. S. Safwan, M. Basir, M. Z. Ramli, "Nickel-Cadmium battery analysis using spectogram", ARPN Journal of Engineering and Applied Sciences, Vol. 11, No. 6, 2016, pp. 3975-3979.

[25] M. Zahran, A. Atef, "Electrical and Thermal Properties of NiCd Battery for Low Earth Orbit Satellite's Applications", Proceedings of the $5^{\text {th }}$ WSEAS International Conference on Power Systems, Lisbon, Portugal, 22-24 September 2006, pp. 122130.

[26] K. H. Young, "Research in Nickel/Metal Hydride Batteries 2017", Batteries, Vol. 4, No. 9, 2018.

[27] S. L. Lin, K. L. Huang, I. C. Wang, I. C. Chou, Y. M. Kuo, C. K. Hung, C. Lin, “Characterization of spent nickel-metal hydridebatteries and a preliminary economic evaluationof the recovery processes", Journal of the Air \& Waste Management Association, Vol. 66, No. 3, 2016, pp. 296-306.

[28] J. Tarabay, N. Karami, "Nickel Metal Hydride Battery: Structure, Chemical Reaction, and Circuit Model", Proceedings of the $3^{\text {rd }}$ International Conference on Technological Advances in Electrical, Electronics and Computer Engineering, Beirut, Lebanon, 29 April - 1 May 2015, pp. 22-26.

[29] K. Saruta, "Long-term Performance of Sodium Sulfur Battery", Proceedings of the IEEE $2^{\text {nd }}$ Annual Southern Power Electronics Conference, Auckland, New Zealand, 5-8 December 2016, pp. 1-5.

[30] Z. Wen, "Study on Energy Storage Technology of Sodium Sulfur Battery and its Application in Power System", Proceedings of the International Conference on Power System Technology, Chongqing, China, 22-26 October 2006.

[31] M. Vins, M. Sirovy, "Sodium-Sulfur Batteries for Energy Storage Applications", Proceedings of the $20^{\text {th }}$ International Scientific Conference on Electric Power Engineering, Kouty nad Desnou, Czech Republic, Czech Republic, 15-17 May 2019.
[32] O. Adeleke, A. Ukil, X. Zhang, "Vanadium Redox \& Lithium Ion Based Multi-Battery Hybrid Energy Storage System for Microgrid", Proceedings of the IEEE PES Asia-Pacific Power and Energy Engineering Conference, Macao, 1-4 December 2019.

[33] Y. R. Challapuram, G. M. Quintero, S. B. Bayne, A. S. Subburaj, M. A. Harral, "Electrical Equivalent Model of Vanadium Redox Flow Battery", Proceedings of the IEEE Green Technologies Conference, Lafayette, LA, USA, 3-6 April 2019.

[34] R. Gupta, N. K. Sharma, P. Tiwari, A. Gupta, N. Nigam, A. Gupta, "Application of energy storage devices in power systems", International Journal of Engineering, Science and Technology, Vol. 2, No. 1, pp. 289-297, 2011.

[35] M. Simeon, A. U. Adoghe, S. T. Wara, J. O. Olowni, "Renewable Energy Integration Enhancement Using Energy Storage Technologies", Proceedings of the IEEE PES/IAS PowerAfrica, Cape Town, South Africa, 28-29 June 2018, pp. 864-868.

[36] M. Miguel, T. Nogueira, F. Martins, “Energy storage for renewable energy integration: the case of Madeira Island, Portugal", Proceedings of the $4^{\text {th }}$ International Conference on Energy and Environment Research, Porto, Portugal, 17-20 July 2017, pp. 251-257.

[37] Y. Hua, X. Shentu, Q. Xie, Y. Ding, "Voltage/Frequency Deviations Control via Distributed Battery Energy Storage System Considering State of Charge", Applied Sciences, Vol. 9, No. 1148, 2019.

[38] T. Tjark, M. Marten, J. Münderlein, H. Axelsen, S. Zurmühlen, M. Leuthold, D. U. Sauer, "Planning of Grid-Scale Battery Energy Storage Systems: Lessons Learned from a 5 MW Hybrid Battery Storage Project in Germany", Proceedings of BattCon, Orlando, Florida, USA, 12-14 May 2015, pp. 1-10.

[39] J. O. Ushie, E. O. Ukem, B. E. Usibe, “Design, construction and testing of an uninterruptible power supply of 300 Watts capacity", Global Journal of Engineering Research, Vol. 11, No. 1, 2012, pp. 1-10.

[40] D. R. Albu, F. V. Popentiu, "High reliability singlephase uninterruptible power supply", Journal of Electrical and Electronics Engineering Research, Vol. 3, No. 2, 2011, pp. 18-26. 